\title{
PYRIMIDINES AS POTENT CYTOTOXIC AND ANTI-INFLAMMATORY AGENTS
}

\author{
ISHWAR BHAT K, ABHISHEK KUMAR* \\ Department of Pharmaceutical Chemistry, NGSM Institute of Pharmaceutical Sciences, Nitte University, Paneer, Deralakatte, Mangalore, \\ Karnataka, India. Email: abhi12bunty@gmail.com
}

Received: 28 January 2016, Revised and Accepted: 21 March 2017

\section{ABSTRACT}

Objective: Many derivatives of pyrimidine are known for the broad-spectrum biological activities such as antimicrobial, antitumor, antibacterial, antitubercular, anti-inflammatory, and cytotoxic activity. Chalcones with an enone group show potent pharmacological activities such as antiinflammatory, antibacterial, antifungal, and antimalarial activity. A series of pyrimidines from chalcones have been synthesized and screened for anti-inflammatory and cytotoxic activity studies.

Methods: Chalcones [1-(4-nitrophenyl)-3-substituted-phenylprop-2-en-1-one] were synthesized from various substituted aldehydes with 4-nitroacetophenone and cyclized with urea and glacial acetic acid to give pyrimidine derivatives [4-(4-nitrophenyl)-6-substituted-phenylpyrimidin-2-ol].

Results: Anti-inflammatory and cytotoxic activity studies revealed that some of the synthesized compounds have shown significant activity.

Conclusion: The observed results proved that pyrimidines are found to be interesting lead molecules for the synthesis of anti-inflammatory and cytotoxic agents.

Keywords: Chalcones, Pyrimidines, Anti-inflammatory activity, Cytotoxic activity.

(C) 2017 The Authors. Published by Innovare Academic Sciences Pvt Ltd. This is an open access article under the CC BY license (http://creativecommons. org/licenses/by/4. 0/) DOI: http://dx.doi.org/10.22159/ajpcr.2017.v10i6.17343

\section{INTRODUCTION}

Pyrimidines are the most important six-membered heterocyclic compounds containing two nitrogen atoms. Pyrimidine occurs in living system in the form of nucleic acid and vitamins. As pyrimidine is a basic nucleus in DNA and RNA, it has been found to be associated with diverse biological activities. The molecule containing pyrimidine nucleus possess wide range of biological activities such as antimalarial [1], antibacterial [2], antifungal [3], anti-inflammatory [4], cytotoxic [5], and antitubercular [6] activity. Furthermore, the intermediates used chalcones are known for their antibacterial [7], antifungal [8], antimalarial [9], and anti-inflammatory [10] activities. By considering the above facts, it was contemplated to synthesize a new series of pyrimidines $\left(\mathrm{PM}_{1}-\mathrm{PM}_{6}\right)$. The final synthesized compounds have been screened for their in vitro antiinflammatory and in vitro cytotoxic activity studies.

\section{METHODS}

Melting points were determined by capillary method and were uncorrected. The infrared (IR) spectra were recorded using Shimadzu Perkin Ekuner-8201 Pc IR spectrometer using a thin film of potassium bromide pellet technique and frequencies are expressed in $\mathrm{cm}^{-1}$. ${ }^{1} \mathrm{H}$ Nuclear magnetic resonance (NMR) spectra were recorded on Bruker Avance 11400 NMR spectrometer. All spectra were taken in $\mathrm{CDCl}_{3}$ and dimethyl sulfoxide (DMSO). Chemical shift values are reported in ppm relative to tetramethylsilane $(\delta=0)$ as an internal standard. Mass spectra were recorded on JeolSX-102/DA-6000 mass spectrometer $(6 \mathrm{kV}, 10 \mathrm{Ma})$ as FAB gas. The purity of the synthesized compounds was checked on silica gel coated plates by using ethyl acetate:Chloroform (9:1) as a solvent and observed in ultraviolet light.

\section{General procedure}

Synthesis of 1-(4-nitrophenyl)-3-substituted-phenylprop-2-en-1one [11]

A mixture of 4-nitroacetophenone $(0.01 \mathrm{~mol})$ and substituted aromatic aldehydes $(0.01 \mathrm{~mol})$ in ethanol $(20 \mathrm{ml})$ were stirred for $24 \mathrm{hrs}$ in the presence of $20 \% \mathrm{NaOH}$ ( $4-5 \mathrm{ml}$ ). The mixture was poured into crushed ice and acidified with $5 \% \mathrm{HCl}$. The product was filtered, washed with water, and recrystallized from ethanol.

Synthesis of 4-(4-nitrophenyl)-6-substituted-phenylpyrimidin-2ol $\left(P M_{1}-P M_{6}\right][12]$

A mixture of substituted chalcones $(0.01 \mathrm{~mol})$ in $20 \mathrm{ml}$ of ethanol/glacial acetic acid and urea $(0.01 \mathrm{~mol})$ in $20 \% \mathrm{NaOH}$ was refluxed for $20 \mathrm{hrs}$. After completion of the reaction, the mixture was poured into ice cold water, filtered, and recrystallized from ethanol. The purity of the compound was checked by TLC using chloroform:Ethyl acetate (1:9) as solvent.

\section{Spectral data}

4-(4-chlorophenyl)-6-(4-nitrophenyl)pyrimidin-2-ol ( $\left.P M_{1}\right)$

IR $(\mathrm{KBr}) \mathrm{cm}^{-1}: 1505(\mathrm{C}=\mathrm{C}$ str), 840(Ar, C-H bend), 3018(Ar, C-H str), 1672(C=N str), 3420(O-H str), 1338(C-N str), 732(C-Cl str); ${ }^{1} \mathrm{H}$ NMR (400 MHz, DMSO-d 6 ): 7.3-7.6 (m, 9H, Ar-H), $8.1(\mathrm{~s}, 1 \mathrm{H}, \mathrm{OH}) ; \mathrm{MS}: \mathrm{m} / \mathrm{z}$ $328(\mathrm{M}+1)$.

\section{4-(4-fluorophenyl)-6-(4-nitrophenyl)pyrimidin-2-ol ( $\left.\mathrm{PM}_{2}\right)$}

IR $(\mathrm{KBr}) \mathrm{cm}^{-1}: 1501(\mathrm{C}=\mathrm{C}$ str), 816(Ar, C-H bend), 3015(Ar, C-H str), 1669 (C=N str), 3432(O-H str), 1335(C-N str), 1286(C-F str); ${ }^{1} \mathrm{H}$ NMR (400 MHz, DMSO-d $\mathrm{d}_{6}$ ) 7.1-7.7 (m, 9H, Ar-H), 8.3 (s, 1H, OH); MS: m/z $295\left(\mathrm{M}^{+}\right)$.

\section{4-(4-hydroxyphenyl)-6-(4-nitrophenyl)pyrimidin-2-ol ( $\left.P M_{3}\right)$}

IR (KBr) $\mathrm{cm}^{-1}$ : 1501(C=C str), 865(Ar, C-H bend), 3010(Ar, C-H str), 1678(C=N str), 3408(O-H str), $1326\left(\mathrm{C}-\mathrm{N}\right.$ str); ${ }^{1} \mathrm{H}$ NMR $(400 \mathrm{MHz}$, DMSO-d $\left.\mathrm{d}_{6}\right)$ 7.1-7.6 (m, 9H, Ar-H), $8.1(\mathrm{~s}, 1 \mathrm{H}, \mathrm{OH}) ; \mathrm{MS}: \mathrm{m} / \mathrm{z} 309\left(\mathrm{M}^{+}\right)$.

\section{Anti-inflammatory activity}

The synthesized compounds were screened for their anti-inflammatory activity using carrageenan-induced rat hind paw edema method [13]. All the experiments were carried out as per the rules and regulations 
of institutional animal ethics committee (Animal Ethics Committee, K.S. Hegde Medical Academy, Deralakatte, Mangalore - 575018 Ref. No. KSHEMA/AEC/31/2010). Results obtained were expressed as mean \pm SEM, and the student's t-test was used to determine the significance difference between the control group and rats treated with the test compounds. Anti-inflammatory activity of synthesized compounds was compared with standard drug diclofenac sodium $10 \mathrm{mg} / \mathrm{kg}$ body weight showing $64.5 \%$ inhibition of rat paw edema whereas tested compounds showed inhibition ranging from $31.52 \%$ to $60.39 \%$ after 120 min. The compounds $\mathrm{PM}_{1}, \mathrm{PM}_{2}, \mathrm{PM}_{5}$, and $\mathrm{PM}_{6}$ showed moderate anti-inflammatory activity compared to the standard drug diclofenac. The results are tabulated in Table 2 .

\section{Cytotoxic activity}

All the test compounds were screened for cytotoxic activity against Ehrlich Ascites Carcinoma (EAC) cells. The tumor cells aspirated from the peritoneal cavity of tumor-bearing mice was washed thrice with normal saline and checked for viability using trypan blue exclusion method [14]. The cell suspension ( 1 million cells in $0.1 \mathrm{ml}$ ) was added to tubes containing various concentrations of the test compounds and volume was made up to $1 \mathrm{ml}$ using phosphate buffered saline. Control tubes contained only cell suspension. The assay mixtures were incubated for $3 \mathrm{hrs}$, at $37^{\circ} \mathrm{C}$, and then, percent of dead cells were evaluated by trypan blue exclusion method. Compounds $\mathrm{PM}_{1}, \mathrm{PM}_{2}, \mathrm{PM}_{5}$, and $\mathrm{PM}_{6}$ induced the greatest effect on EAC cells with an activity more than $60 \%$ at a concentration of $200 \mu \mathrm{g} / \mathrm{ml}$. The results are summarized in Table 3 .

\section{RESULTS AND DISCUSSION}

Anti-inflammatory activity

The in vivo anti-inflammatory activity of the synthesized compounds by carrageenan-induced rat hind paw edema method showed that compounds $\mathrm{PM}_{1}, \mathrm{PM}_{2}, \mathrm{PM}_{5}$, and $\mathrm{PM}_{6}$ exhibited significant activity. The presence of pyrimidine moiety with electron withdrawing groups

Table 1: Physicochemical data of the synthesized Pyrimidine derivatives $\left(\mathrm{PM}_{1}-\mathrm{PM}_{6}\right)$

\begin{tabular}{|c|c|c|c|c|c|}
\hline Compound code & $\mathbf{R}$ & Molecule weight & M.P ${ }^{\circ} \mathrm{C}$ & Physical state & $\%$ yield \\
\hline $\mathrm{PM}_{1}$ & $4-\mathrm{Cl}$ & 327 & $222-224$ & White crystals & 67 \\
\hline $\mathrm{PM}_{2}^{1}$ & $4-F$ & 295 & $210-212$ & Brown crystals & 70 \\
\hline $\mathrm{PM}_{3}^{2}$ & $3-\mathrm{OH}$ & 309 & $231-233$ & White crystals & 64 \\
\hline $\mathrm{PM}_{4}^{3}$ & $4-\mathrm{CH}_{3}$ & 307 & $251-253$ & Brown crystals & 78 \\
\hline $\mathrm{PM}_{5}^{4}$ & $3-\mathrm{NO}_{2}^{3}$ & 324 & $230-232$ & Yellow crystals & 71 \\
\hline $\mathrm{PM}_{6}^{5}$ & $4-\mathrm{CN}^{2}$ & 304 & $240-242$ & White crystals & 80 \\
\hline
\end{tabular}

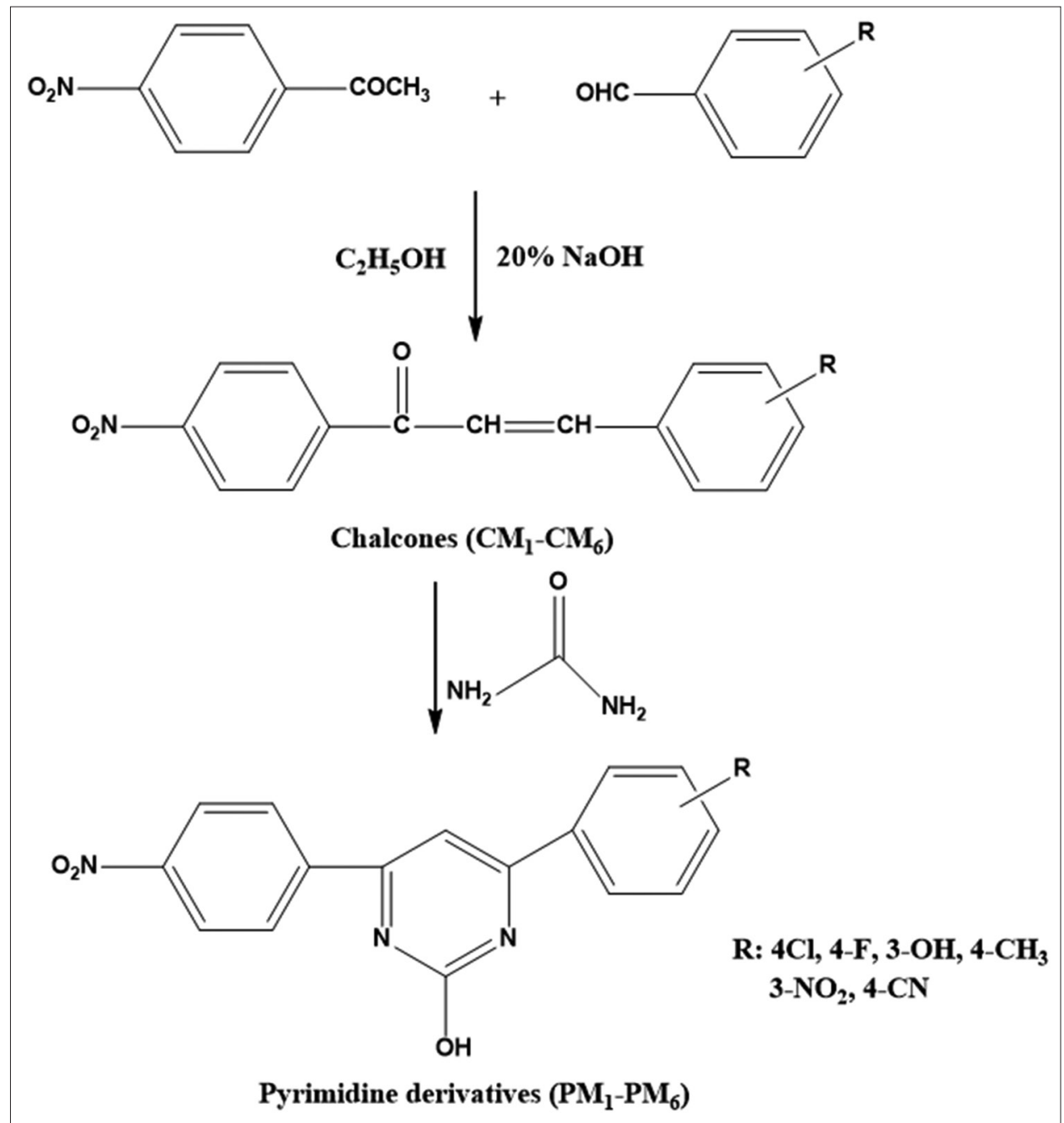

Fig. 1: Scheme for pyrimidine derivatives 
Table 2: Anti-inflammatory activity of compounds (PM1-PM6) by carrageenan-induced paw edema in rats

\begin{tabular}{|c|c|c|c|c|c|}
\hline \multirow[t]{2}{*}{ Treatment } & \multirow[t]{2}{*}{ Dose mg/kg } & \multicolumn{4}{|c|}{ Increase in the paw edema volume $(\mathrm{ml})$} \\
\hline & & $1 \mathrm{hr}$ & $2 \mathrm{hrs}$ & $3 \mathrm{hrs}$ & $4 \mathrm{hrs}$ \\
\hline Control & Vehicle & $0.2726 \pm 0.0291$ & $0.3615 \pm 0.02914$ & $0.375 \pm 0.021$ & $0.3814 \pm 0.021$ \\
\hline PM1 & 50 & $\begin{array}{l}0.2136 \pm 0.021 \\
(28.9)\end{array}$ & $\begin{array}{l}0.1896 \pm 0.016^{* *} \\
(47.9)\end{array}$ & $\begin{array}{l}0.46 \pm 0.02^{* *} \\
(51.4)\end{array}$ & $\begin{array}{l}0.53 \pm 0.02^{* *} \\
(57.8)\end{array}$ \\
\hline PM2 & 50 & $\begin{array}{l}0.1931 \pm 0.005^{*} \\
(36.5)\end{array}$ & $\begin{array}{l}0.169 \pm 0.006^{* *} \\
(57.1)\end{array}$ & $\begin{array}{l}0.1921 \pm 0.021^{* *} \\
(53.1)\end{array}$ & $\begin{array}{l}0.172 \pm 0.021^{* *} \\
(60.39)\end{array}$ \\
\hline PM3 & 50 & $\begin{array}{l}0.182 \pm 0.181^{*} \\
(36.5)\end{array}$ & $\begin{array}{l}0.271 \pm 0.005 \\
(31.1)\end{array}$ & $\begin{array}{l}0.245 \pm 0.081 \\
(30.6)\end{array}$ & $\begin{array}{l}0.259 \pm 0.051 \\
(31.52)\end{array}$ \\
\hline PM4 & 50 & $\begin{array}{l}0.1962 \pm 0.0012 \\
(32.4)\end{array}$ & $\begin{array}{l}0.2014 \pm 0.006 \\
(41.4)\end{array}$ & $\begin{array}{l}0.2516 \pm 0.021 \\
(34.6)\end{array}$ & $\begin{array}{l}0.221 \pm 0.06 \\
(41.4)\end{array}$ \\
\hline PM5 & 50 & $\begin{array}{l}0.1892 \pm 0.02^{* *} \\
(34.9)\end{array}$ & $\begin{array}{l}0.1762 \pm 0.006^{* *} \\
(35.6)\end{array}$ & $\begin{array}{l}0.189 \pm 0.017^{* *} \\
(51.4)\end{array}$ & $\begin{array}{l}0.172 \pm 0.025^{* *} \\
(59.1)\end{array}$ \\
\hline PM6 & 50 & $\begin{array}{l}0.1913 \pm 0.02 \\
(33.1)\end{array}$ & $\begin{array}{l}0.176 \pm 0.006^{* *} \\
(53.1)\end{array}$ & $\begin{array}{l}0.196 \pm 0.021^{* *} \\
(53.5)\end{array}$ & $\begin{array}{l}0.1612 \pm 0.025^{* *} \\
(58.1)\end{array}$ \\
\hline
\end{tabular}

All values are expressed as mean \pm SEM $(\mathrm{n}=6),{ }^{*} \mathrm{p}<0.05$ significant compared to control, ${ }^{* *} \mathrm{p}<0.01$ significant compared to control

Table 3: Cytotoxic activity studies of compounds $\left(\mathrm{PM}_{1}-\mathrm{PM}_{6}\right)$ by trypan blue exclusion method

\begin{tabular}{llllll}
\hline Compounds & \multicolumn{5}{l}{$\begin{array}{l}\text { Number of dead cells (\%) at different } \\
\text { concentrations }(\boldsymbol{\mu g} / \mathbf{m l})\end{array}$} \\
\cline { 2 - 6 } & $\mathbf{1 0}$ & $\mathbf{2 0}$ & $\mathbf{5 0}$ & $\mathbf{1 0 0}$ & $\mathbf{2 0 0}$ \\
\hline Control & - & - & - & - & - \\
$\mathrm{PM}_{1}$ & 13 & 32 & 43 & 61 & 69 \\
$\mathrm{PM}_{2}$ & 14 & 30 & 44 & 58 & 70 \\
$\mathrm{PM}_{3}$ & 06 & 18 & 23 & 34 & 44 \\
$\mathrm{PM}_{4}$ & 07 & 16 & 20 & 29 & 41 \\
$\mathrm{PM}_{5}$ & 14 & 31 & 45 & 61 & 69 \\
$\mathrm{PM}_{6}$ & 12 & 34 & 46 & 66 & 71 \\
5 -fluorouracil & 20 & 35 & 50 & 85 & 95 \\
\hline
\end{tabular}

such as chloro, fluoro, nitro, and cyano accounted for significant antiinflammatory activity.

\section{Cytotoxic activity}

The test compounds were screened for their cytotoxic activity against EAC cells using trypan blue exclusion method. Compounds $\mathrm{PM}_{1}, \mathrm{PM}_{2^{\prime}}$ $\mathrm{PM}_{5}$, and $\mathrm{PM}_{6}$ induced significant effect on EAC cells with an activity more than $60 \%$ at a concentration of $200 \mu \mathrm{g} / \mathrm{ml}$. The presence of pyrimidine moiety with substitution and group such as chloro, fluoro, nitro, and cyano has accounted for their remarkable cytotoxic activity.

\section{CONCLUSION}

Most of the synthesized compounds resulted in good yield, and most of them showed potent anti-inflammatory and cytotoxic activities.

\section{ACKNOWLEDGMENT}

The authors are thankful to Nitte University for providing the necessary facilities to carry out this work. The authors are grateful to Head, SAIF, Panjab University, Chandigarh, for providing spectroscopic data and Amala Cancer Research Centre, Thrissur, for providing cytotoxic activity facilities.

\section{REFERENCES}

1. Singh K, Kaur T. Pyrimidine-based antimalarials: Design strategies and antiplasmodial agents. Med Chem Commun 2016;7:749-68.

2. Bansal S, Chaudhary AN, Kothiyal P. Microwave assisted synthesis and antibacterial activity of pyrimidine derivatives. Ind J Pharm Pharm Sci 2013;5(1):346-48.

3. Dudhe R, Sharma PK, Verma PK. Pyrimidine containing furanose derivative having antifungal, antioxidant and cytotoxic activity. Org Med Chem Lett 2014;4(1):3.

4. El-Gazzar AR, Hussein H, Hafez H. Synthesis and biological evaluation of thieno [2,3-d] pyrimidine derivatives for anti-inflammatory, analgesic and ulcerogenic activity. Acta Pharm 2007;57(4):395-11.

5. Rostom SA, Ashour HM, El Razik HA. Synthesis and biological evaluation of some novel polysubstituted pyrimidine derivatives as potential antimicrobial and anticancer agents. Arch Pharm 2009;342(5):299-10.

6. Hussain MM, Bhat KI, Revanasiddappa BC. Synthesis and biological evaluation of some novel 2-mercapto pyrimidines. Ind J Pharm Pharm Sci 2013;5(2):471-3

7. Chikhalia KH, Patel MJ, Dhaval BV. Design, synthesis and evaluation of novel quinolyl chalcones as antibacterial agents. ARKIVOC 2008;XIII:189-97.

8. Gupta D, Jain DK. Chalcone derivatives as potential antifungal agents: Synthesis and antifungal activity. J Adv Pharm Technol Res 2015;6(3):114-7.

9. Todigoppula N, Korthikunta V, Gupta S. Synthesis and insight into the structure-activity relationships of chalcones as antimalarial agents. J Med Chem 2013;56(1):31-45.

10. Hsieh HK, Tsao LT, Wang JP, Lin CN. Synthesis and anti-inflammatory effect of chalcones. J Pharm Pharmacol 2000;52(2):163-71.

11. Bhat KI, Kumar A, Nissar M, Kumar P. Synthesis, pharmacological and biological screening of some novel pyrimidine derivatives. Med Chem Res 2014;23(7):3458-67.

12. Bhat KI, Kumar A, Thara PV, Kumar P. Synthesis, characterization and biological activity studies of some substituted pyrimidine derivatives. Indian J Heterocycl Chem 2014;23:271-6.

13. Winter CA, Risley EA, Nuss GW. Carrageenin-induced edema in hind paw of the rats as an assay for anti-inflammatory drugs. Proc Soc Exp Biol Med 1962;111:544-7.

14. Louis KS, Siegel AC. Cell viability analysis using trypan blue: Manual and automated methods. Methods Mol Bio 2011;740:7-12. 